\title{
Trade and overcoming land constraints in British industrialization: an empirical assessment*
}

\author{
Dimitrios Theodoridis ${ }^{1}$, Paul Warde ${ }^{2}$ and Astrid Kander ${ }^{3}$ \\ ${ }^{1}$ Department of Economy and Society, Gothenburg University, Box 625, 40530 Göteborg, Sweden \\ E-mail: dimitrios.theodoridis@gu.se \\ ${ }^{2}$ Faculty of History, University of Cambridge, West Road, Cambridge CB3 9EF, UK \\ E-mail: psw1000@cam.ac.uk \\ ${ }^{3}$ Department of Economic History, Lund University, P.O. Box 7083, SE-220 07 Lund, Sweden \\ E-mail: astrid.kander@ekh.lu.se
}

\begin{abstract}
Land was an unambiguous constraint for growth in the pre-industrial period. In Britain it was overcome partly through the transition from traditional land-based goods to coal (vertical expansion) and partly through accessing overseas land, primarily from colonies (horizontal expansion). Kenneth Pomeranz suggested that horizontal expansion may have outweighed vertical expansion in the first decades of the nineteenth century. Taking a more complete approach to trade, we find that Britain was a net exporter of land embodied in traded commodities, apart from in the early nineteenth century, when potash (rather than cotton or timber) constituted the major land-demanding import from North America. The vertical expansion was generally larger than the horizontal expansion. In other words, Britain was not simply appropriating flows of land and resources from abroad but simultaneously providing its trading partners with even more land-expanding resources.
\end{abstract}

Keywords coal, colonies, ghost acres, Industrial Revolution, trade

\section{Introduction}

The Industrial Revolution in Britain is often associated with the expansion of available 'land' beyond the surface area of the island to vertical (coal) and horizontal (colonial) 'frontiers' that

* We would like to thank the audience at the Sixteenth Century Society and Conference in Vancouver, Canada (October 2015), where we first presented a portion of this work. Their helpful questions aided us in developing this article as did those by the participants at the workshop 'Translation in transit: interpreting culture in the modern world', held at the European University Institute in Fiesole, Italy (May 2017). We are also grateful to Richard L. Kagan, Jorge Flores, Alyson Price, Paul Nelles, Audrey Millet, and José Juan Pérez Meléndez, as well as to the Journal's editors and the two anonymous reviewers for their vital interventions in earlier drafts. 
hugely augmented available resources. Kenneth Pomeranz pointed to both these impacts in his widely influential book The great divergence, and argued that the role of horizontal expansion in particular had been neglected in the previous literature. ${ }^{1}$ This analysis was consistent with a number of influential analyses that defined the essential growth constraint of the pre-industrial economy as being a land constraint. ${ }^{2}$ The surface of the Earth is limited and, more pertinently, the surface which particular groups of people can make productive at a given level of technology is constrained. Nearly all commodities in the pre-industrial economy depended on land, and even the processing of minerals and metals relied on wooded areas for fuel. In a preindustrial economy, this limit is expressed most starkly in the food supply, given the restricted capacity of plants to photosynthesize solar energy and draw nutrients from the soil. ${ }^{3}$

Undoubtedly, improvements in land productivity were made in pre-industrial times, but coal was a remedy to this land constraint in a more profound way. By being able to draw on an enormous stock of energy, rather than the annual flow of solar radiation as mediated (rather inefficiently) by plants, the resource base could become much larger. Coal was available in a punctiform manner, meaning that deposits were concentrated in seams providing a condensed energy source which, compared to using firewood, freed up land for other purposes. The punctiform availability of coal, a heavy commodity to transport, meant that it could be exploited in intense clusters of activity, reaping economies of scale and concentration. Thus Britain during the Industrial Revolution opened what Edward Barbier termed a 'vertical land frontier of expansion'. ${ }^{4}$

International trade also presented options for certain countries to be released from the narrow constraint of their own surface area, through 'horizontal land expansion'. Powerful core countries could expand access to resources by effectively occupying and exploiting more space in peripheral countries. This could take the form of voluntary migrations and exchanges, or that of coercion: the option of colonies. Utilizing other countries' ecological space as a means to expand the resource base is, needless to say, also not sustainable in the long run, because it cannot be a universal option for expansion and growth. There is only one Earth.

The Industrial Revolution in Britain is often associated with a period of horizontal 'frontier' expansion, one that led to major extensions of the cultivated area in many parts of the world, the acceleration of deforestation, and the development of mining. ${ }^{5}$ But the empirical evidence is

1 Kenneth Pomeranz, The great divergence: China, Europe, and the making of the modern world economy, Princeton, NJ: Princeton University Press, 2000.

2 A sample of this literature includes E. A. Wrigley, Continuity, chance and change: the character of the Industrial Revolution in England, Cambridge: Cambridge University Press, 1988; E. A. Wrigley, Energy and the English Industrial Revolution, Cambridge: Cambridge University Press, 2010; E. A. Wrigley, The path to sustained growth: England's transition from an organic economy to an industrial revolution, Cambridge: Cambridge University Press, 2016; Rolf Peter Sieferle, The subterranean forest: energy systems and the industrial revolution, Cambridge: White Horse Press, 2001; Pomeranz, Great divergence; Astrid Kander, Paolo Malanima, and Paul Warde, Power to the people: energy in Europe over the last five centuries, Princeton: Princeton University Press, 2013.

3 Wrigley, Path to sustained growth; Thomas Robert Malthus, An essay on the principle of population, London: J. Johnson, 1798.

4 Edward Barbier, Scarcity and frontiers: how economies have developed through natural resource exploitation, Cambridge: Cambridge University Press, 2011.

5 Indicative work which deals extensively with the issue of horizontal frontier expansion is Eric Eustace Williams, Capitalism and slavery, London: A. Deutsch, 1944; Walter Prescott Webb, The great frontier, Lincoln, NE: University of Nebraska Press, 1964; Joan Martinez-Alier, 'Marxism, social metabolism, and international trade', in Alf Hornborg, John Robert McNeill, and Joan Martinez-Alier, eds., Rethinking environmental history: world-system history and global environmental change, Walnut Creek, CA: AltaMira Press, 2007, pp. 221-37; Pomeranz, Great divergence; Barbier, Scarcity and frontiers; Stephen G. Bunker and Paul S. Ciccantell, Globalization and the race for resources, Baltimore, MD: Johns Hopkins University Press, 
meagre on exactly how large this horizontal land expansion during British industrialization was. No all-encompassing assessment of the land embodied in British trade (both imports and exports) has yet been carried out. To remedy this, our article will provide such accounts for the first time. In this we follow the approach of Pomeranz, but, rather than relying on estimates derived from only a few products, our work will attempt a much more comprehensive assessment of the land impact of trade, and provide ranges of possible values. Additionally, we consider the imports and exports both of products primarily based on the land, and also of those primarily based on coal used for their production. This enables a reassessment of Pomeranz's argument about the relative role of coal and colonies, and also extends the analysis in time from the classic period of the Industrial Revolution (c.1770-1830) into the subsequent decades, which saw much more significant quantitative growth, and up to what Kevin O'Rourke and Alan M. Taylor have identified as the age of the 'first globalization' on the basis of commodity and factor price convergence. ${ }^{6}$ Indeed, while there has been some debate as to the extent of earlier price convergence, ${ }^{7}$ what this empirical reconstruction is able to show is the enormous expansion of demand for land by a metropolitan economy in the latter part of the nineteenth century.

While others have disputed whether horizontal additions to the national land area were a necessary condition of early British industrialization, none have denied that they were significant additions as the economy grew in the Victorian era. ${ }^{8}$ In this article we provide a much more detailed quantification of the flow of land resources (or, in the case of coal, land substitutes) in and out of Britain throughout the nineteenth century, and their net balance; equally, we assess the domestic mining and consumption of coal as an indigenous substitute for land. Aside from making the 'land-augmenting' effects of trade and mining clear, this will also enable us to answer the question of what contributed more, in a strictly quantitative sense, to overcoming land constraints - domestic fossil energy or overseas land? How did this vary over time and what form did these land resources take? ${ }^{9}$ It is clear that the answers to these questions are to some degree determined by methodological preferences. By providing a first attempt at a complete accounting of such flows, allied with an explicit presentation of methodologies employed, we are able to provide both an empirical basis for such discussions and a clear sense of what is at stake in particular methodological choices.

The second and third sections provide an overview of previous research and historical theorizing, while the fourth describes our data and basic methods in assessing land needs. The

2005; Alf Hornborg, 'Footprints in the cotton fields: the Industrial Revolution as time-space appropriation and environmental load displacement', Ecological Economics, 59, 1, 2006, pp. 74-81; Alf Hornborg, Global ecology and unequal exchange: fetishism in a zero-sum world, New York: Routledge, 2011; Michael Williams, Deforesting the Earth: from prehistory to global crisis, Chicago, IL: University of Chicago Press, 2006; Joseph E. Inikori, Africans and the Industrial Revolution in England: a study in international trade and economic development, New York: Cambridge University Press, 2002.

6 Kevin H. O’Rourke, Alan M. Taylor, and Jeffrey G. Williamson, 'Factor price convergence in the late nineteenth century', International Economic Review, 37, 3, 1996, pp. 499-530; Kevin H. O'Rourke and Jeffrey G. Williamson, 'When did globalization begin?', European Review of Economic History, 6, 1, 2002, pp. 23-50.

$7 \quad$ Klas Rönnbäck, 'Integration of global commodity markets in the early modern era', European Review of Economic History, 13, 1, 2009, pp. 95-120.

8 Studies that have questioned the role of trade and imperial expansion for industrialization include Paul Bairoch, Economics and world history: myths and paradoxes, London: Harvester Wheatsheaf, 1993; Patrick O'Brien, 'European economic development: the contribution of the periphery', Economic History Review, 35, 1, 1982, pp. 1-18.

9 On land augmentation, see Paolo Malanima, 'Energy consumption in England and Italy, 1560-1913: two pathways toward energy transition', Economic History Review, 69, 1, 2016, pp. 78-103. 
fifth section reports the results, and the final one concludes with a discussion of these results and their implications for further research.

\section{Frontier expansion and unbalanced trade}

The role of coal as a land saver and an important aspect of the Industrial Revolution is hardly questioned among economic historians today, with rare exceptions. ${ }^{10}$ Instead, several books and studies in recent years have returned to earlier assertions of the major role of coal in industrialization. ${ }^{11}$ Yet few studies apart from Pomeranz's work have taken up the more difficult issue of horizontal land expansion, very probably because of the difficulty of providing a quantitative assessment. This article is written with some inspiration from ecological economics, which typically investigates the flows and interrelatedness between the economic system and the physical realities that underpin the system. In that sense, it is a back-projection of modern analyses of carrying capacity and ecological footprints into the past of British industrialization. $^{12}$

World system theory suggests that, in order to understand development and global history, it is necessary to investigate trade flows and the interconnectedness of countries. ${ }^{13} \mathrm{~A}$ range of thinkers and studies have explored what is called unequal exchange in trade: that is, systematic biases in trade that mean rich countries benefit more than poor countries, whether through setting them on particular developmental trajectories, or through making certain countries more vulnerable to shifting terms of trade. ${ }^{14}$ This is a complex and contested topic; we agree that there is no reason to believe that the gains from trade according to Ricardian comparative advantages are necessarily equally (or fairly) distributed among the trading

10 Gregory Clark and David Jacks, 'Coal and the industrial revolution, 1700-1869', European Review of Economic History, 11, 1, 2007, pp. 39-72; Joel Mokyr, 'The intellectual origins of modern economic growth', Journal of Economic History, 65, 2, 2005, pp. 285-351; Deirdre N. McCloskey, Bourgeois dignity: why economics can't explain the modern world, Chicago, IL: University of Chicago Press, 2010.

11 Wrigley, Energy; Wrigley, Path to sustained growth; Robert C. Allen, The British Industrial Revolution in global perspective, Cambridge: Cambridge University Press, 2009; Robert C. Allen, 'Why the industrial revolution was British: commerce, induced invention, and the scientific revolution', Economic History Review, 64, 2, 2011, pp. 357-84; Kander, Malanima, and Warde, Power to the people; Alan Fernihough and Kevin H. O'Rourke, 'Coal and the European Industrial Revolution', National Bureau of Economic Research Working Paper no. 19802, 2014.

12 For a survey of this tradition, see Martinez-Alier, 'Marxism, social metabolism, and international trade'; Manuel González de Molina and Víctor M. Toledo, The social metabolism: a socio-ecological theory of historical change, Cham: Springer International Publishing, 2014.

13 Immanuel Wallerstein, The modern world-system, vol. 1: Capitalist agriculture and the origins of the European world-economy in the sixteenth century, New York: Academic Press, 1974; Immanuel Wallerstein, The modern world-system, vol. 2: Mercantilism and the consolidation of the European world-economy, 1600-1750, New York: Academic Press, 1980; Immanuel Wallerstein, The modern world-system, vol. 3: The second great expansion of the capitalist world-economy, 1730-1840s, San Diego, CA: Academic Press, 1989; Kevin H. O'Rourke and Jeffrey Williamson, Globalization and history: the evolution of a nineteenth-century Atlantic economy, Cambridge, MA: MIT Press, 1999; Ronald Findlay and Kevin H. O'Rourke, Power and plenty: trade, war, and the world economy in the second millennium, Princeton, NJ: Princeton University Press, 2007.

14 Two of the earlier attempts to study unequal exchange through trade were the studies by Hans W. Singer, 'The distribution of gains between investing and borrowing countries', American Economic Review, 40, 2, 1950, pp. 473-85, and Raul Prebisch, 'The economic development of Latin America and its principal problems', Economic Bulletin for Latin America, 7, 1950, which also set the ground for what was later called the 'Prebisch-Singer hypothesis'. Other studies dealing with unequal exchange are Arghiri Emmanuel, Unequal exchange: a study of the imperialism of trade, New York: Monthly Review Press, 1972; Stephen G. Bunker, Underdeveloping the Amazon: extraction, unequal exchange, and the failure of the modern state, Urbana, IL: University of Illinois Press, 1985; Hornborg, Global ecology. 
partners. However, in this article we do not aim to assess whether Britain gained more from trade than its trading partners, nor the long-term implications of specialization. Our aim is more limited, but perhaps no less important: to provide a clear empirical basis for assessing the scale of flows and their impact. Our focus is on two physical factors embodied in trade: land and coal, using the metric of land area, which is based on actual land utilized for the land-demanding agricultural and raw material goods; and, in the case of coal, land saved by the use of the fossil fuel.

To our knowledge there is only one other study that examines the balance of trade for Britain during the same period from an ecological perspective. Heinz Schandl and Niels Schulz use the approach of 'social metabolism', studying how many metric tonnes of physical matter are consumed in the core countries, but brought from the periphery. ${ }^{15}$ They performed a decomposition of the material flows of British trade in imports and exports between 1850 and 1997. It turns out that the traded tonnage was fairly balanced during the second half of the nineteenth century, but that Britain then became a net exporter on an increasing scale up until the First World War. In 1852, imports accounted for 5.1 million metric tonnes versus 4.9 million metric tonnes of exports; by 1869 , exports made up 14.2 million metric tonnes as opposed to 11.5 million tonnes for imports. By 1913, the level of physical exports had reached more than double the level of imports, at 102.3 million metric tonnes, while imports were only 45 million metric tonnes. Although Schandl and Schulz's study is consistent in accounting for both imports and exports, it does not allow for the relative importance of different commodities in alleviating the land constraint, nor do they attempt to measure this directly or tackle the question of unequal exchange.

Our study is limited in the sense that it deals with unbalanced exchange of land embodied in trade, and not with labour or capital embodied in that trade. This means that conclusions regarding unequal exchange and exploitation should be avoided until more evidence is available. A basic observation is that nearly all frontier expansion by the European empires resulted in the large-scale expropriation of native peoples. But horizontal frontier expansion during the nineteenth century involved labour in different ways depending on the resources involved, and those labour regimes also shifted over time. ${ }^{16}$ Some frontier expansion operated in conditions of relative labour scarcity, which in certain circumstances stimulated the imposition of coercive labour regimes, while other expansion occurred in conditions of relatively plentiful cheap labour. Similarly, some products were so demanding of land as to be only viable in conditions where land was abundant, making land rents effectively negligible, whereas other products required considerable capital investment for their extraction.

One example of the latter is potash, a product that has received virtually no attention in the previous literature, especially for the nineteenth century. ${ }^{17}$ Our study identifies this as a very significant commodity in terms of demands on land, and one which in turn was used as a chemical input to many crucial processes in early industrialization: bleaching and washing of textiles, glass-making, and ceramics. This is precisely the kind of result that emerges from a thorough, rather than a partial, investigation. Potash was largely supplied by farmers engaged

15 Heinz Schandl and Niels Schulz, 'Changes in the United Kingdom's natural relations in terms of society's metabolism and land-use from 1850 to the present day', Ecological Economics, 41, 2, 2002, pp. 203-21.

16 Barbier, Scarcity and frontiers.

17 Paul Warde, 'Trees, trade and textiles: potash imports and ecological dependency in British industry, c.15501770', Past \& Present, forthcoming. 
in land clearance for agriculture. ${ }^{18}$ This makes it unusual in that its supply was a by-product of another activity, rather than a development of horizontal expansion with a view towards supplying core industrial regions. Nor was it a substitute for previous domestic supplies, as it had largely been imported to north-west Europe since medieval times, such was the landextensive nature of its production. In this case, globalization was an extension of a horizontal frontier that had previously been more regionally constrained.

Viewed from the perspective of Britain, however, the import of potash underlines how British development required a continually expanding land frontier where rents were very low, and, in purely quantitative terms, one that before 1850 was orientated not so much towards fibres for textile production as towards the alkali content of plants for chemical processing. In the late eighteenth century, for example, the potash frontier was still in New England and upstate New York. By 1840, it had moved with the settlement frontier to those parts of Ohio and New York bordering Lake Erie, and into Upper Canada (Ontario) from an earlier focus on the St Lawrence river. In fact, so concentrated was this activity on the frontier that in 1840 some $46 \%$ of recorded US production came from two counties in Ohio. In this regard, some of the expansion of the horizontal frontier was curiously like that of the vertical frontier: intensely extracting from the most easily available seams of coal, and moving deeper into an accumulated stock of energy.

The case of potash also highlights the fact that all horizontal expansion was not alike. Different kinds of traded goods, and different wage/rent ratios, might imply rather different kinds of labour regimes, with their associated methods of coercion, and different environmental impact. These will not be dealt with in this article, but are indicated as topics for future research that can now proceed more comparatively on the basis of quantitative evidence. ${ }^{19}$

\section{Ghost acres and ecological footprints}

For assessing vertical and horizontal frontier expansion, previous studies have resorted to the concepts of 'ghost acres' and 'ecological footprints'. The idea of 'ghost acres' was posited by Georg Borgström as a measure of the area of land abroad that a country required to meet those of its consumption needs that were not satisfied by domestic sources. It should be noted that this did not necessarily imply a direct substitution, as it may be the case that the land abroad was used to produce goods that were never available domestically. Equally, domestic land may have been used to produce goods that were once sourced from abroad - as is frequently the case with processes of trade specialization. ${ }^{20}$ The concept of 'ghost acres' has been one aspect of the argument that an expanding colonial land frontier was essential for underwriting British industrialization, most notably as presented by Pomeranz. It was, however, only made on the basis of assessing a limited number of imported goods at some early benchmark dates.

The modern 'ecological footprint' approach takes a more complete view of trade, but there are important differences between our work and most research in this tradition, which assumes

18 Michael Williams, 'Products of the forest: mapping the census of 1840', Journal of Forest History, 24, 1, 1980, pp. 4-23; Harry Miller, 'Potash from wood ashes: frontier technology in Canada and the United States', Technology and Culture, 21, 2, 1980, pp. 187-208; Robert P. Multhauf, 'Potash', in Brooke Hindle, ed., Material culture of the wooden age, Tarrytown, NY: Sleepy Hollow Press, 1981, pp. 227-40.

19 One of the authors has a more detailed study of these questions in preparation.

20 Georg Borgström, The hungry planet: the modern world at the edge of famine, New York: Macmillan, 1965. 
standardized technologies and land productivity. ${ }^{21}$ In contrast, we use maximum and minimum figures to show a range of possible demand for overseas land, based on the spread of countries from which imports came, or uncertainties regarding data quality. Land productivity can be different according to the various land uses and the quality of that land itself, which may be more or less suited to particular uses. Our approach seeks to minimize uncertainties around different productivities of land, although we only include lands that were at some point used for producing a particular good.

To account for fossil fuels, ecological footprint studies use three different approaches for converting them to a corresponding land area. ${ }^{22}$ Each approach is built on a different rationale. The first method assesses the area of forest growth that would have been required to act as a sink for the released carbon dioxide. The second method calculates the land that would be required to replace fossil fuels with the use of a biologically produced substitute (for example, methanol from wood). The third approach estimates the necessary land area to rebuild natural capital at the same rate as the fossil fuel is consumed. As our concern is with constraints and resource availability, we follow the second approach focusing on the substitute: wood. In other words, we estimate how much land would have been needed to provide the same amount of energy as fossil fuels from a sustainable yield of wood, based on empirical data on wood yields. Our method is consistent with modern ecological footprint accounts, while, according to Wackernagel and Rees, all three methods give roughly the same result in units of land. Nevertheless, as they suggest, 'the $\mathrm{CO}_{2}$ assimilation method results in the smallest ecological footprint attributable to fossil fuel consumption'. ${ }^{23}$

The classic triumvirate of products in the British Industrial Revolution are cotton, iron, and coal. Pomeranz's pioneering study made a rough calculation and suggested raw cotton imports (along with those of less significance - sugar and timber) to be even more important, in purely quantitative terms, than coal consumption in liberating Britain from its land constraints, at least in the period he studied before the mid nineteenth century. In particular, Pomeranz estimated that the imports of these three products were substantial: adding around twenty-five to thirty million acres to the economy, perhaps half the utilizable national area. We should note that Pomeranz was making an argument about the importance of both horizontal and vertical expansion, and providing a rough order of magnitude of the contribution of each in overcoming the land constraint. This is not the same as judging a larger figure for, say, horizontal expansion as indicating more significance in the broader question of what permitted the industrialization process itself.

\section{Data and methods}

The trade data pertaining to the United Kingdom of Great Britain and Ireland from the early nineteenth century to the early twentieth is one of the main sources used in this study. The main aim is to capture the development of trade throughout the nineteenth century and up until the end of the first era of intense globalization. In particular, data from the 'Trade and navigation accounts' from the House of Commons Parliamentary Papers are used for the benchmark years

21 On the ecological footprint, see Mathis Wackernagel and William E. Rees, Our ecological footprint: reducing human impact on the Earth, Canada: New Society Publishers, 1996.

22 Ibid., pp. 71-3.

23 Ibid., p. 71. 
1832, 1849, 1870, and 1907. Aside from data availability, these years have been selected in order to cover significant events throughout the nineteenth century (the consolidation of the Industrial Revolution, the liberalization of trade marked by the abolition of Corn Laws, the grain invasion, and the period of intense globalization). For the first benchmark year, 1832, exports were reported only in values. For this reason, the export quantities of key commodities analysed in this study were obtained from secondary sources. For coal, iron, and steel exports, and other non-ferrous metals, data from Brian Mitchell's work were used. ${ }^{24}$ For cotton manufactures, wool, and woollen manufactures, data were obtained from Edward Baines's and James Bischoff's original work. ${ }^{25}$

We now describe our basic method in assessing land needs. Regarding the conversion factors used, a detailed discussion on each commodity and the sources used can be found in previous research by Theodoridis and Warde. ${ }^{26}$ Further details on the methodological approach are also provided in Appendix 1.

Our calculations are not based on examining trade data in terms of their economic value, as is usual, but from an ecological perspective, calculating the flows of goods and the land or land equivalents that they represent. We take our inspiration in part from Pomeranz's analysis, but it also serves to highlight methodological issues that should be discussed. For example, Pomeranz compared coal consumption figures in 1815 with the scale of cotton imports in 1830 , which at first glance may seem reasonable, but actually by 1830 coal consumption had nearly doubled. This would bias any comparison between coal and cotton in favour of cotton, by a factor of two. The lesson from this is that, if one wants to compare the relative size of contributions to the expanding land frontier in a period of relatively rapid change, it is important to do so for the same benchmark years.

For many products, a 'ghost acres' analysis that tries to measure the counterfactual impact on demand for domestic land, did imports not exist, must face the problem that, in a counterfactual world that never materialized, the entire structure of demand would probably be different. Unsurprisingly, there is no standard unit of land required to produce any good; the area has varied over time and places in response to technology, social organization, and environmental conditions. Equally, the question arises as to whether the 'ghost acreage' of raw cotton imports, for example, is best understood in relation to the actual acres used for the production of cotton at any given moment, or the acres that might have been required for the domestic production of a substitute, as Pomeranz argued in the case of wool replacing cotton. Acquiring wool was highly demanding of land, requiring around twenty times more land than cotton per ton produced. It should be noted, however, that other alternatives could be theoretically available. Previous research has suggested alternatives such as linen could have replaced some - although probably not all - of the demand for cotton (and indeed ones that

24 B. R. Mitchell, British historical statistics, Cambridge: Cambridge University Press, 1988, pp. 257, $300,319$.

25 Edward Baines, History of the cotton manufacture in Great Britain: with a notice of its early history in the East, and in all the quarters of the globe, London: H. Fisher, R. Fisher and P. Jackson, 1835, p. 367; James Bischoff, A comprehensive history of the woollen and worsted manufactures and the natural and commercial history of sheep, from the earliest records to the present period, vol. 2, London: Smith, Elder, 1842, fig. VII.

26 For a detailed discussion on how the acreage and coal conversion factors of each product has been calculated see Dimitrios Theodoridis, 'The ecological footprint of early-modern commodities: coefficients of land use per unit of product', Göteborg Papers in Economic History, 21, 2017, https://gupea.ub.gu.se/handle/2077/51684 (consulted 14 February 2017); Paul Warde, 'Energy embodied in traded goods for the United Kingdom, 18701935: discussion of methods and sources', Energy History, 2016, http://www.fas.harvard.edu/ histecon/ energyhistory/British_energy_multipliers_Warde_Nov_2016.pdf (consulted 14 February 2017). 
could be combined with cotton in the production of certain cloths). ${ }^{27}$ We do not rule out the utility of such exercises per se, but we prefer to start from the empirical ground of what horizontal expansion did, in fact, occur. This has the advantage of also connecting ecological demands more directly to the specific labour regimes that were utilized to meet them. Clearly this approach does not indicate in itself what the demand for land might have been in an alternative scenario, and in some cases it would bias the release from the land constraint downwards.

However, this simple method obviously cannot be applied in the case of coal. Fortunately, we can reasonably state that, in this case, only one plausible alternative fuel - wood - was available, which itself was a relatively (but not entirely) homogenous product, and that this product could be grown in most countries. While other land-based fuels could be available, including crop residues or animal dung, they would have required much more land and labour than wood and nowhere in Europe did they constitute a major fuel input. Peat might have been employed as a substitute, although that was itself already quite intensively exploited and thus was a less viable alternative to coal. Unlike coal, neither peat nor firewood was ever exported on any scale (in contrast to the more valuable timber). The degree to which coal consumption assisted in overcoming the land constraint has been measured, in line with Wrigley's and Pomeranz's work on this theme, by the acreage of woodland that would have been required to sustainably produce the same amount of heat content.

That said, Pomeranz's choice of a 'land equivalent' for coal, although being more cautious about the sustainable yield in forestry than Wrigley had been before him, employed what we believe to be a very optimistic figure from Vaclav Smil. ${ }^{28}$ By optimistic, we mean that the yield estimate employed still overestimated actual forest yield that can be empirically assessed. Their estimates on sustainable forest yields per acre were too high for Britain, almost double what is achieved in the British deciduous woodlands today and which probably prevailed over time. Wrigley's estimate of a sustainable yield was 2 imperial tons of dry wood per acre while Smil's world average estimate, which Pomeranz used, was 1.45 imperial tons per acre. We estimate a more plausible yield to be approximately 0.85 imperial tons per acre. Also, in order to allow for a margin of error, we use a range of 0.85-1.2 imperial tons per acre, the upper limit being the minimum average estimate for northern Europe and the USA. ${ }^{29}$ These figures indicate that both Pomeranz and Wrigley tended to produce rather conservative figures as to the degree to which the expansion of the vertical frontier helped eliminate land constraints. With a lower yield, such as the one we employ, more land would be needed to replace coal.

Lastly, another reason that justifies the use of a counterfactual approach in the particular case of coal is the need for standardization between imports and exports. In order to be able to compare the relative roles of vertical and horizontal expansion, as well as to indicate the overall release from a land constraint, we need a common unit of measurement - in this case,

27 Giorgio Riello, Cotton: the fabric that made the modern world, Cambridge: Cambridge University Press, 2013, pp. 240-4. However, as he argues, problems with the plausibility of this counterfactual can still arise, given that flax, although it shares material properties with cotton, is significantly more labour-intensive in its processing.

28 Wrigley, Continuity, chance and change, pp. 54-5; Vaclav Smil, Biomass energies: resources, links, constraints, New York: Plenum, 1983, p. 36; Pomeranz, Great divergence, p. 276.

29 For a detailed discussion on the acreage conversion factor of coal : wood, see Theodoridis, 'Ecological footprint'. 
land. In other words, the establishment of a common unit of measurement for 'landdemanding' products abroad and 'land-alleviating' products at home is necessary.

It is important to stress that our measures include indirect inputs into land in the shape of fuel used in the extraction or manufacturing of exports, and not just direct inputs (to grow a crop, for example) or the raw materials embodied in final goods. This is particularly important in assessing the contribution of coal that was consumed during the production of exported goods, and hence is treated as an 'embodied' input of resources measured by the land equivalent of firewood that would have been required to substitute the coal. Such relationships cannot be traced exhaustively and some boundary-setting is required, but we have been able to establish the significant flows of indirect fuel use.

It is not a simple matter to draw the 'boundaries' in such trade accounts. In the case of animal products, only direct land requirements are measured, but in modern applications of this method, such as the ecological footprint accounting methods of Mathis Wackernagel and William Rees, the built environment (meaning space occupied by buildings) and other indirect inputs such as food for workers might also be included. ${ }^{30}$ One could argue that, in the case of cotton, for example, one should include the land required to grow fodder for draught animals and to provide food for the workers in the cotton fields. However, exactly the same goes for the food of miners who extracted coal that was exported from Britain, or indeed worked in cotton factories or iron foundries that produced for export. It may be argued that, in any given year, these inputs would have existed in the economy anyway and would simply be allocated elsewhere if not used in a traded good. They do not affect the direct flows of embodied land, although the overall shape of trade and economy and its dependency on the land in the long run will be affected if different traded goods have different factor inputs (being more labour- or capital-intensive). This is a question for further research, but for reasons of logic and simplicity we thus set a boundary that neglects the land providing food and fodder, which is only an indirect input into the traded goods. This is assumed to belong to the stock of land of the trading nations; in other words, at any given point in time it is assumed that such land would have to be dedicated to keeping people and animals alive irrespective of whether their labour was devoted to traded goods or not.

It is frequently the case that a product is not exclusively imported or exported, and it is the balance of land required that is the object of this particular article. Britain, for example, both imported and exported copper or iron and steel products in any given year. What needs to be noted is that, owing to lack of available information, for some manufactured products the same technical coefficient is used for both imports and exports and is based on coal used in production processes in the UK. This means that, for instance, imports of iron manufactures are converted on the basis of the technology which prevailed in Britain rather than that which prevailed in the export country. Although this introduces some degree of bias, we do not believe that it seriously affects our results, for two main reasons. First, for the most important products - pig iron, iron and steel, and cotton manufactures - the share of imports relative to exports is very small (approximately $5 \%$ or less in most benchmark years). Second, products for which imports are higher than exports hold a relatively very small share in total coal embodied in exports. In other words, the imports of these goods are not significant enough to alter the results.

30 For a detailed discussion on the ecological footprint concept, see Wackernagel and Rees, Our ecological footprint. 
We must stress that the results presented here are contingent on the conversion factors that have been used. For this reason we have used a minimum and maximum estimate in order to strengthen our analysis and not bias it towards a particular outcome. Given the big difference between the maximum estimate of imports and the minimum estimate of exports of land in all benchmark years, it can safely be argued that slightly different conversion factors would not change the overall picture and the conclusions. Indeed, as noted above, our use of conversion factors from 1870 in calculations for earlier years means that the land embodied in exports could be underestimated, given productivity improvements and technological changes that took place between 1830 and 1870 . Nevertheless, changes in the land embodied in exports are driven by iron and steel exports, where our information is most reliable.

It may also be questioned whether the conversion of more commodities would alter the results. From the import side this is very unlikely. For instance, even for the years when trade had intensified significantly, 1870 and 1907, the commodities which have not been included in our final calculations made up only $7 \%$ and $15 \%$ respectively of the total import value. In other words, the vast majority of imports have been converted, and the inclusion of the rest of the commodities would not alter the general conclusions in any significant way. The same observation applies to exports. Given what we know about the allocation of domestic coal consumption within industry, none of them can have consumed enough coal in their production to alter these results.

What should be noted, however, is that some products may have had a relatively low significance in value terms and may also have required little land for their production but have had a significant bearing on land productivity in Britain. Such, for example, were internationally traded fertilizers, which were obtained via the expansion of colonial power and trade and contributed in saving land through technical change. Technical change undoubtedly contributed to some land saving in Britain, but the focus of this study is mainly on vertical and horizontal land expansion. We are concerned with the question of whether relieving spatial constraints in Britain generated spatial constraints abroad and not with every single thing that made land more productive. Nevertheless, to get an indication of scale, we can provide some estimates for one of the most important productivity-enhancing imported goods that has frequently been mentioned in the literature: guano. We find that the effects of guano imports from 1840 s onwards were relatively small. Based on nineteenth-century sources focusing on guano applications, 200 pounds or 2 hundredweight of guano was applied on land sown with wheat, while the productivity increase per acre was approximately $25 \% .{ }^{31}$ Given the size of guano imports in 1849 and 1870, their land-augmenting effect could have amounted to roughly 200,000-700,000 acres for each benchmark year. ${ }^{32}$ Under the light of this study's results, this

31 For estimates on guano application and productivity per acre in Britain and the US, see John C. Nesbit, On agricultural chemistry: and the nature and properties of Peruvian guano, London: Longman and Co., 1856, pp. 31, 98-116; Dave Hollett, More precious than gold: the story of the Peruvian guano trade, Cranbury, NJ: Associated University Press, 2008, pp. 102, 105; Gregory T. Cushman, Guano and the opening of the Pacific world: a global ecological history, Cambridge: Cambridge University Press, 2012, p. 79; The Country Gentleman, 4, 25, 1854, p. 390.

32 Guano imports to Britain were around 82,000 and 280,000 imperial tons respectively in 1849 and 1870. They peaked in 1858 at approximately 300,000 tons according to W. M. Mathew, 'Peru and the British guano market, 1840-1870', Economic History Review, 23, 1, 1970, pp. 112-28. These should be considered optimistic estimates, since lands sown with crops other than wheat would have required a much higher application of guano per acre, in some cases even double. 
amounts to barely more than $1 \%$ of the land savings from vertical expansion and less than $1 \%$ of the savings from horizontal expansion in 1870 .

Aside from fertilizers, there were other means by which resource availability could be expanded, often linked with technical change. One such area did not involve the land at all: the commodities from the sea, whether for food consumption or to provide lighting or lubricants, as in the case of whale oil. We do not consider this as an expansion of 'ghost acres' but rather as a technological improvement in harvesting what is in the sea, the impact of which would be difficult to translate into land and which would need to be calculated on the basis of complex counterfactual scenarios. Nevertheless, it would certainly be desirable for such research to be conducted on alleviating resource constraints, and the scale of ecological impact.

Another issue that needs to be noted concerns the calculation of land equivalents and problems related with double counting. We have tried to avoid problems of double counting as much as possible. For instance, we have considered only the most land-demanding by-products that come from a single source. However, we acknowledge that this practice is nonproblematic only when looking at land dependencies of particular nations (as is the case in this study) but not when generalized on a global scale. For wood products, and particularly wood ash, this issue becomes particularly important, since it could be argued that the woodland provides more than one service. It can be a source for wood but also, when cleared, it is used for agriculture. In this respect, the question arises of whether it is reasonable to attribute all of the land that is used for say potash production to that particular commodity or whether it should instead be allocated to its various uses?

For this particular study, this may not constitute a serious concern for the following reasons. First, we are calculating the British requirements and, in this sense, from the British point of view, this amount of land would have been required to produce potash irrespective of what it was used for afterwards. Even more so, we know that trade is somewhat specialized. In this sense, Britain was not necessarily importing the majority of its grain from British North America, where the forest was cleared to provide wood and wood products. Grain imports to Britain from North America were very small before the 1850s and did not become the dominant share until the late nineteenth century. Nevertheless, given that we recognize the potential bias involved, we return to this issue in discussing the results, providing a sensitivity analysis.

\section{Results}

Our estimates of the coal embodied in the net exports of commodities for all benchmark years are presented in Table 1. Accordingly, the results on land embodied in net imports are presented in Tables 2-5 under each year. It should be stressed that these tables constitute a summary and do not list all the commodities which have been converted (for that, see Appendix 2). Instead, the most important commodities which embody most of the input in land or coal are presented, while the rest are captured under the category 'Other'. Finally, Table 6 is a summary table, where the trade balance of land embodied in net imports and net exports is presented under each year. To account for a margin of error in the conversion factors used and to ensure the validity of our results, we have calculated a minimum and maximum estimate of land embodied in trade. 
Table 1. Net exports of coal and coal embodied in goods for 1832, 1849, 1870, and 1907

\begin{tabular}{|c|c|c|c|c|c|c|c|}
\hline & $\begin{array}{l}\text { Significant } \\
\text { goods }\end{array}$ & & $\begin{array}{l}\text { Exports } \\
\text { (metric } \\
\text { tonnes) }\end{array}$ & $\begin{array}{l}\text { Imports } \\
\text { (metric } \\
\text { tonnes) }\end{array}$ & $\begin{array}{l}\text { Net exports } \\
\text { (metric } \\
\text { tonnes) }\end{array}$ & $\begin{array}{l}\text { Conversion factor } \\
\text { (tonnes of coal } \\
\text { equivalent } \\
\text { per tonne) }\end{array}$ & $\begin{array}{c}\text { Coal in net } \\
\text { exports } \\
\text { (metric tonnes) }\end{array}$ \\
\hline \multirow[t]{7}{*}{1832} & Cotton & Goods & 71,302 & - & 71,302 & 7.3 & 520,505 \\
\hline & Coal & & 597,436 & - & 597,436 & 1.06 & 633,282 \\
\hline & Pig iron & & 18,288 & - & 18,288 & 3.56 & 65,105 \\
\hline & Iron \& steel & & 132,087 & 20,188 & 111,899 & 6.91 & 773,222 \\
\hline & Other metals & Copper & 10,668 & 35 & 10,633 & 18 & 191,394 \\
\hline & & Lead & 12,396 & 1,107 & 11,289 & 1.5 & 16,934 \\
\hline & & Tin & 1,626 & 1,484 & 142 & 1 & 142 \\
\hline \multirow{12}{*}{$\begin{array}{l}\text { Total } \\
1849\end{array}$} & & & & & & & $2,200,584$ \\
\hline & Alkali soda & & 34,920 & - & 34,920 & 4.01 & 140,029 \\
\hline & Cotton & Goods & 200,836 & 188 & 200,648 & 7.3 & $1,464,730$ \\
\hline & Coal & & $2,876,287$ & - & $2,876,287$ & 1.06 & $3,048,864$ \\
\hline & Pig iron & & 165,147 & - & 165,147 & 3.56 & 587,923 \\
\hline & Iron \& steel & & 556,739 & 29,919 & 526,820 & 6.91 & $3,640,326$ \\
\hline & Other metals & Copper & 21,872 & 2,241 & 19,631 & 18 & 353,358 \\
\hline & & Lead & 17,290 & 7,450 & 9,840 & 1.5 & 14,760 \\
\hline & & Zinc & - & 802 & -802 & 4 & $-3,208$ \\
\hline & & Tin & 1,792 & 1,806 & -14 & 1 & -14 \\
\hline & Sugar & Refined & 11,324 & 15,099 & $-3,775$ & 0.47 & $-1,774$ \\
\hline & Woollen & Goods & 46,782 & - & 46,782 & 10.63 & 497,293 \\
\hline \multirow{12}{*}{$\begin{array}{l}\text { Total } \\
1870\end{array}$} & & & & & & & $9,742,287$ \\
\hline & Alkali soda & & 195,952 & - & 195,952 & 4.01 & 785,768 \\
\hline & Cotton & Goods & 384,117 & - & 384,117 & 7.3 & $2,804,054$ \\
\hline & Coal & & $11,679,553$ & $38,886^{\mathrm{a}}$ & $11,640,667$ & 1.06 & $12,339,107$ \\
\hline & Pig iron & & 764,759 & - & 764,759 & 2.73 & $2,087,792$ \\
\hline & Iron $\&$ steel & & $1,995,287$ & 99,460 & $1,895,827$ & 6.06 & $11,488,712$ \\
\hline & Other metals & Copper & 41,977 & 29,976 & 12,001 & 18 & 216,018 \\
\hline & & Lead & 51,964 & 53,528 & $-1,564$ & 1.5 & $-2,346$ \\
\hline & & Zinc & 148,929 & 29,187 & 119,742 & 4 & 478,968 \\
\hline & & Tin & $2,138,160$ & 4,791 & $2,133,369$ & 1 & $2,133,369$ \\
\hline & Sugar & Refined & 28,725 & 86,894 & $-58,169$ & 0.47 & $-27,339$ \\
\hline & Woollen & Goods & 75,452 & 15,816 & 59,636 & 10.63 & 633,931 \\
\hline \multirow{12}{*}{$\begin{array}{l}\text { Total } \\
1907\end{array}$} & & & & & & & $32,938,034$ \\
\hline & Cotton & Goods & 695,106 & 6,762 & 688,344 & 6 & $4,130,064$ \\
\hline & Coal \& Coke & & $67,123,573$ & $1,759,578^{a}$ & $65,363,995$ & 1.06 & $69,285,835$ \\
\hline & Pig iron & & $1,980,071$ & 105,046 & $1,875,025$ & 2.24 & $4,200,056$ \\
\hline & Iron $\&$ steel & & $3,270,829$ & 842,609 & $2,428,220$ & 3.38 & $8,207,384$ \\
\hline & Other metals & Copper & 50,324 & 68,799 & $-18,475$ & 1 & $-18,475$ \\
\hline & & Lead & 44,014 & 207,980 & $-163,966$ & 1 & $-163,966$ \\
\hline & & Zinc & 6,666 & 110,924 & $-104,258$ & 1 & $-104,258$ \\
\hline & & Tin & 8,669 & 44,507 & $-35,838$ & 1 & $-35,838$ \\
\hline & Sugar & & 33,685 & 986,071 & $-952,386$ & 0.47 & $-447,621$ \\
\hline & Woollen & Goods & 129,620 & 90,324 & 39,296 & 8.95 & 351,699 \\
\hline & Machinery & Engines & 728,094 & 88,203 & 639,891 & 5.04 & $3,225,051$ \\
\hline Total & & & & & & & $88,629,931$ \\
\hline
\end{tabular}

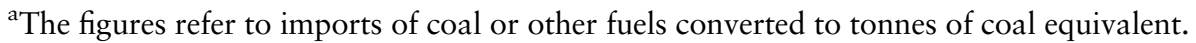
Sources: Trade data are from the 'Trade and navigation accounts', House of Commons Parliamentary Papers; and Mitchell, British historical statistics, pp. 257, 300, 319. For the conversion factors, see Warde, 'Energy embodied in traded goods'.

Our results are somewhat different from Pomeranz's work, which has stressed the role of land embodied in key imports such as cotton, wood, and sugar. ${ }^{33}$ In fact, it turns out that, by taking a more systematic and inclusive account of trade a different, more complicated story emerges. As can be seen in Table 6, Britain was, indeed, a net importer of 'land' in 1832, and

33 Pomeranz, The Great Divergence, p. 276, pp. 313-15. 
reliant on ghost acres overseas, as land embodied in net imports was almost twice the land embodied in exports. Nevertheless, the reasons for this trade deficit are not to be found in the commodities commonly perceived to be of key importance by economic historians. In particular, instead of cotton, wood, and sugar, by far the biggest contribution comes from potash imports (Table 2). Additionally, for wool, a far more land-intensive commodity than cotton, exports were much larger than imports, creating a land-export surplus of approximately 3-6 million acres. Sheep on British hills were suppliers of overseas markets. Another reason for this trade deficit is that, by 1832, the iron and steel industry was not yet exporting as much it would by 1849 , when pig iron exports had increased by a factor of nine.

Although the UK was a net importer of land in 1832, the situation soon changed drastically, and persisted for the rest of the period until the onset of the First World War. From 1849 onwards, the results clearly suggest that UK was a net exporter of land or land equivalents (Table 6). Even by taking the extreme scenarios as a sensitivity analysis, namely the maximum estimate of net imports and the minimum estimates of net exports, we can clearly reject the hypothesis that the UK was a net importer of land-equivalent natural capital. The most pronounced surplus is found for the benchmark year 1870, when land embodied in net exports was more than double that embodied in net imports. This is a surprising result, especially given increasing trade openness and the rising importance of agricultural imports flowing towards Britain - what has famously been termed the 'European grain invasion'. ${ }^{34}$ By 1849 , however, grain was already more important than cotton in net terms, as much of the cotton was reexported in a more finished form. Thus the impact on land use of the British consumer had become more pronounced through grain than cotton by 1849 . This was even clearer by 1907 , as incomes rose and the net inflow of land embodied in butter became larger than that of cotton, and the absolute level of land embodied in imports of grain had outstripped that in cotton.

We also see that from 1849 onwards the surpluses of land in the trade balance were not simply driven by the use of coal embodied in export manufactures. Re-exports of raw wool and woollen and worsted textiles were a significant counterbalance to wool imports. To be more specific, it can be seen in Table 3 that, as for 1832, raw wool imports were actually significantly lower than the total weight of wool exports, and consequently land embodied in exports (from $65 \%$ to $75 \%$ lower). This means that, even excluding the export of 'land' acquired virtually in the form of its 'vertical frontier' of coal mining, Britain was a net exporter of a significant amount of actual land-based products (utilizing around 3.6-7.3 million acres). By 1870 and 1907, wool imports had increased to such an extent that they had overtaken the wool embodied in exports (Tables 4 and 5). However, re-exports of woollen manufactures again utilized a significant share of land embodied in imports. For instance, out of the approximately 21-43 million acres imported, approximately 13 million and 24 million were re-exported in the form of manufactures (Table 4). These large re-exports of textile manufactures significantly reduced the net balance of imported land after 1840 .

Nevertheless, the most significant contribution was actually made by the vertical frontier of coal mining, and the export of Britain's coal reserves, whether directly or in embodied form. By

34 For discussion of the 'grain invasion', see Kevin H. O’Rourke, 'The European grain invasion, 1870-1913', Journal of Economic History, 57, 4, 1997, pp. 775-801; Paul Sharp and Jacob Weisdorf, 'Globalization revisited: market integration and the wheat trade between North America and Britain from the eighteenth century', Explorations in Economic History, 50, 1, 2013, pp. 88-98. 
Table 2. Net imports of land embodied in goods in 1832, in acres

\begin{tabular}{|c|c|c|c|c|c|c|c|c|c|}
\hline \multirow[b]{3}{*}{ Significant goods } & & & \multirow{3}{*}{$\begin{array}{l}\text { Imports } \\
\text { (tonnes) }\end{array}$} & \multirow{3}{*}{$\begin{array}{l}\text { Exports } \\
\text { (tonnes) }\end{array}$} & \multirow{3}{*}{$\begin{array}{c}\mathrm{C}=\mathrm{A}-\mathrm{B} \\
\text { Net imports } \\
\text { (tonnes) }\end{array}$} & \multicolumn{2}{|c|}{$\mathrm{D}$} & \multicolumn{2}{|c|}{$\mathrm{E}=\mathrm{C} / \mathrm{D}$} \\
\hline & & & & & & \multicolumn{2}{|c|}{$\begin{array}{l}\text { Conversion factor } \\
\text { (tonnes per acre) }\end{array}$} & \multicolumn{2}{|c|}{$\begin{array}{l}\text { Imported land equivalents } \\
\qquad \text { (acres) }\end{array}$} \\
\hline & & & & & & Maximum & Minimum & Minimum & Maximum \\
\hline Ashes, pearl and pot & & & 9,656 & & 9,656 & 0.000781 & 0.000625 & $12,363,636$ & $15,449,600$ \\
\hline \multirow[t]{3}{*}{ Wool } & Raw & & 12,759 & 1,905 & 10,854 & 0.00544 & 0.00272 & $1,995,221$ & $3,990,441$ \\
\hline & Yarn in raw wool equivalent & & & 1,538 & $-1,538$ & 0.00544 & 0.00272 & $-282,721$ & $-565,441$ \\
\hline & Goods in raw wool equivalent & & & 25,536 & $-25,536$ & 0.00544 & 0.00272 & $-4,694,118$ & $-9,388,235$ \\
\hline Total & & & & & & & & $-2,981,618$ & $-5,963,235$ \\
\hline \multirow[t]{9}{*}{ Cotton } & Raw & Brit. America & 775 & & 775 & 0.032 & 0.020 & 24,219 & 38,750 \\
\hline & & Brit. E. Indies & 15,957 & & 15,957 & 0.082 & 0.036 & 194,598 & 443,250 \\
\hline & & US & 99,680 & & 99,680 & 0.100 & 0.082 & 996,800 & $1,215,610$ \\
\hline & & Brazil & 9,122 & & 9,122 & 0.100 & 0.082 & 91,220 & 111,244 \\
\hline & & Egypt & 4,003 & & 4,003 & 0.159 & 0.091 & 25,176 & 43,989 \\
\hline & & Other & 569 & & 569 & 0.095 & 0.064 & 5,989 & 8,891 \\
\hline & & Total & & & & & & $1,338,002$ & $1,861,734$ \\
\hline & Yarn in raw cotton equivalent & & & 34,749 & $-34,749$ & 0.095 & 0.064 & $-365,779$ & $-542,953$ \\
\hline & Goods in raw cotton equivalent & & & 44,475 & $-44,475$ & 0.095 & 0.064 & $-468,158$ & $-694,922$ \\
\hline Total & & & & & & & & 504,065 & 623,859 \\
\hline Grain & Wheat & & 88,114 & & 88,114 & 0.562 & 0.287 & 156,786 & 307,017 \\
\hline Butter & & & 6,651 & & 6,651 & 0.0 & & 163,818 & 163,818 \\
\hline Wood $^{\text {a }}$ & & & $365,275,800$ & & $365,275,800$ & 530 & 424 & 689,200 & 861,500 \\
\hline Other ${ }^{\mathrm{b}}$ & & & & & & & & $4,081,602$ & $5,395,987$ \\
\hline Sum & & & & & & & & $14,977,489$ & $16,838,546$ \\
\hline
\end{tabular}

${ }^{a}$ Wood imports and the conversion factors are in units of volume (board feet).

bProducts labelled as 'other' are reported in detail in Appendix 1.

Sources: Trade data are from the 'Trade and navigation accounts', House of Commons Parliamentary Papers; Baines, History of the cotton manufacture, p. 367; Bischoff, Comprehensive history of the woollen and worsted manufactures, table VII; and the 'Ledgers of imports under countries - CUST 4'. For the conversion factors, see Theodoridis, 'Ecological footprint'. 
Table 3. Net imports of land embodied in goods in 1849 , in acres

\begin{tabular}{|c|c|c|c|c|c|c|c|c|}
\hline \multirow{3}{*}{\multicolumn{2}{|c|}{ Significant goods }} & \multirow{3}{*}{$\begin{array}{l}\text { Imports } \\
\text { (tonnes) }\end{array}$} & \multirow{3}{*}{$\begin{array}{c}\text { B } \\
\text { Exports } \\
\text { (tonnes) }\end{array}$} & \multirow{3}{*}{$\begin{array}{c}\mathrm{C}=\mathrm{A}-\mathrm{B} \\
\begin{array}{c}\text { Net imports } \\
\text { (tonnes) }\end{array}\end{array}$} & \multicolumn{2}{|c|}{$\mathrm{D}$} & \multicolumn{2}{|c|}{$\mathrm{E}=\mathrm{C} / \mathrm{D}$} \\
\hline & & & & & \multicolumn{2}{|c|}{$\begin{array}{l}\text { Conversion factor } \\
\text { (tonnes per acre) }\end{array}$} & \multicolumn{2}{|c|}{$\begin{array}{l}\text { Imported land equivalents } \\
\qquad \text { (acres) }\end{array}$} \\
\hline & & & & & Maximum & Minimum & Minimum & Maximum \\
\hline $\begin{array}{l}\text { Ashes, } \\
\text { pearl } \\
\text { and pot }\end{array}$ & & 8,054 & & 8,054 & 0.000781 & 0.000625 & $10,312,420$ & $12,886,400$ \\
\hline \multirow[t]{3}{*}{ Wool } & Raw & 34,816 & 5,027 & 29,789 & 0.00544 & 0.00272 & $5,475,919$ & $10,951,838$ \\
\hline & $\begin{array}{l}\text { Yarn in raw wool } \\
\text { equivalent }\end{array}$ & & 8,233 & $-8,233$ & 0.00544 & 0.00272 & $-1,513,419$ & $-3,026,838$ \\
\hline & $\begin{array}{l}\text { Goods in raw } \\
\text { wool equivalent }\end{array}$ & & 41,430 & $-41,430$ & 0.00544 & 0.00272 & $-7,615,809$ & $-15,231,618$ \\
\hline Total & & & & & & & $-3,653,309$ & $-7,306,618$ \\
\hline \multirow{3}{*}{ Cotton } & Raw & 342,675 & & 342,675 & 0.09525 & 0.06350 & $3,597,638$ & $5,396,457$ \\
\hline & $\begin{array}{l}\text { Yarn in raw } \\
\text { cotton } \\
\text { equivalent }\end{array}$ & 208 & 77,843 & $-77,635$ & 0.09525 & 0.06350 & $-815,066$ & $-1,222,598$ \\
\hline & $\begin{array}{l}\text { Goods in raw } \\
\text { cotton } \\
\text { equivalent }\end{array}$ & & 130,777 & $-130,777$ & 0.09525 & 0.06350 & $-1,372,987$ & $-2,059,480$ \\
\hline \multirow{6}{*}{$\begin{array}{l}\text { Total } \\
\text { Grain } \\
\text { Butter } \\
\text { Wood }^{\text {a }} \\
\text { Other }^{b} \\
\text { Sum }\end{array}$} & & & \multirow{6}{*}{3,198} & & \multirow{2}{*}{\multicolumn{2}{|c|}{$0.562 \quad 0.287$}} & $1,409,585$ & $2,114,379$ \\
\hline & Wheat & 871,160 & & 871,160 & & & $1,550,107$ & $3,035,401$ \\
\hline & & 14,352 & & 11,154 & \multirow{4}{*}{\multicolumn{2}{|c|}{$\begin{array}{r}0.04060 \\
424\end{array}$}} & 274,729 & 274,729 \\
\hline & & $979,628,400$ & & $979,628,400$ & & & $1,848,355$ & $2,310,444$ \\
\hline & & & & & & & $8,057,877$ & $10,862,066$ \\
\hline & & & & & & & $19,799,764$ & $24,176,801$ \\
\hline
\end{tabular}

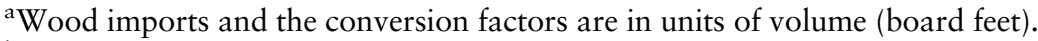

'Products labelled as 'other' are reported in detail in Appendix 1.

Sources: Trade data are from the 'Trade and navigation accounts', House of Commons Parliamentary Papers; and the 'Ledgers of imports under countries - CUST 4'. For the conversion factors, see Theodoridis, 'Ecological footprint'.

1849, the sum of land embodied in imports and the sum of land equivalents of coal exports (actual and embodied) was probably roughly equal (Tables 3 and 6). In net terms, however, as Britain imported next to no coal (actual or embodied) but exported much of its textile production, the vertical frontier was already larger in these exchanges, and the gap between the vertical frontier and the horizontal expanded over time. At the three earlier benchmark dates, it was the coal embodied in exports that was the most significant factor in the role of this vertical frontier in trade - that is, the coal combusted to produce products within Britain that were then exported overseas (Table 1). Among these goods, by far the biggest contribution came from pig iron, and iron and steel manufactured goods, followed by coal used in the manufacture of textiles. The iron and steel industry was the most energy intensive in nineteenth-century Britain and thus the biggest single consumer of coal. In all our benchmark years, coal embodied in pig iron and iron and steel goods accounted for almost $60 \%$ of total coal embodied in exported manufactures. Textiles, predominately cottons, are by far the next biggest group, accounting for up to $30 \%$ of the total in 1849 and 1907 . Over time the coal embodied in coal (or coke) itself as an export product became increasingly significant, at around $15 \%$ of the total by 1907 . All other products were relatively marginal. 
Table 4. Net imports of land embodied in goods in 1870, in acres

\begin{tabular}{|c|c|c|c|c|c|c|c|c|c|}
\hline \multirow[b]{3}{*}{ Significant goods } & & & \multirow{3}{*}{$\begin{array}{l}\text { Imports } \\
\text { (tonnes) }\end{array}$} & \multirow{2}{*}{ B } & \multirow{2}{*}{$\mathrm{C}=\mathrm{A}-\mathrm{B}$} & \multicolumn{2}{|c|}{$\mathrm{D}$} & \multicolumn{2}{|c|}{$\mathrm{E}=\mathrm{C} / \mathrm{D}$} \\
\hline & & & & & & \multicolumn{2}{|c|}{$\begin{array}{l}\text { Conversion factor } \\
\text { (tonnes per acre) }\end{array}$} & \multicolumn{2}{|c|}{$\begin{array}{l}\text { Imported land equivalents } \\
\text { (acres) }\end{array}$} \\
\hline & & & & (tonnes) & (tonnes) & Maximum & $\overline{\text { Minimum }}$ & Minimum & Maximum \\
\hline \multirow{4}{*}{$\begin{array}{l}\text { Ashes, pearl and pot } \\
\text { Wool }\end{array}$} & & & 4,056 & & 4,056 & 0.000781 & 0.000625 & $5,193,342$ & $6,489,600$ \\
\hline & Raw & & 120,805 & 4,094 & 116,711 & 0.00544 & 0.00272 & $21,454,228$ & $42,908,456$ \\
\hline & Yarn & l equivalent & 7,184 & 25,528 & $-18,344$ & 0.00544 & 0.00272 & $-3,372,059$ & $-6,744,118$ \\
\hline & Good & ool equivalent & 11,146 & 58,859 & $-47,713$ & 0.00544 & 0.00272 & $-8,770,772$ & $-17,541,544$ \\
\hline \multirow{10}{*}{$\begin{array}{l}\text { Total } \\
\text { Cotton }\end{array}$} & & & & & & & & $9,311,397$ & $18,622,794$ \\
\hline & Raw & US & 324,883 & & 324,883 & 0.09979 & 0.08165 & $3,255,667$ & $3,978,971$ \\
\hline & & Brazil & 28,895 & & 28,895 & 0.09979 & 0.08165 & 289,558 & 353,889 \\
\hline & & Turkey & 4,322 & & 4,322 & 0.09525 & 0.06350 & 45,375 & 68,063 \\
\hline & & Egypt & 65,181 & & 65,181 & 0.15876 & 0.09072 & 410,563 & 718,485 \\
\hline & & Br. India & 154,947 & & 154,947 & 0.08165 & 0.03629 & $1,897,697$ & $4,269,689$ \\
\hline & & Other & 27,944 & & 27,944 & 0.09525 & 0.06350 & 293,375 & 440,063 \\
\hline & & Total & & & & & & $6,192,236$ & $9,829,160$ \\
\hline & Yarn & on equivalent & & 97,603 & $-97,603$ & 0.09525 & 0.06350 & $-1,024,703$ & $-1,537,055$ \\
\hline & Good & tton equivalent & & 296,274 & $-296,274$ & 0.09525 & 0.06350 & $-3,110,488$ & $-4,665,732$ \\
\hline Total & & & & & & & & $2,057,045$ & $3,626,372$ \\
\hline Grain & Whea & & $1,576,201$ & & $1,576,201$ & 0.562 & 0.287 & $2,804,628$ & $5,491,990$ \\
\hline Butter & & & 58,904 & 2,921 & 55,983 & & & $1,378,892$ & $1,378,892$ \\
\hline Wood $^{\text {a }}$ & & & $2,457,183,600$ & & $2,457,183,600$ & 530 & 424 & $4,636,195$ & $5,795,244$ \\
\hline Other ${ }^{b}$ & & & & & & & & $15,984,653$ & $21,600,728$ \\
\hline Sum & & & & & & & & $41,366,152$ & $63,005,620$ \\
\hline
\end{tabular}

${ }^{\mathrm{a}}$ Wood imports and the conversion factors are in units of volume (board feet).

${ }^{\text {bProducts labelled as 'other' are reported in detail in Appendix } 1 .}$

Sources: Trade data are from the 'Trade and navigation accounts', House of Commons Parliamentary Papers; and the 'Ledgers of imports under countries CUST 4'. For the conversion factors, see Theodoridis, 'Ecological footprint'. 
Table 5. Net imports of land embodied in goods in 1907, in acres 
Table 6. Land embodied in exports and imports in 1832, 1849, 1870, and 1907, minimum and maximum estimates

\begin{tabular}{|c|c|c|c|c|c|c|c|c|c|}
\hline \multirow[b]{3}{*}{ Year } & \multirow{3}{*}{$\begin{array}{c}\text { A } \\
\text { Net exports of } \\
\text { coal and coal } \\
\text { embodied in } \\
\text { goods, } \\
(1,000 \text { metric } \\
\text { tonnes })\end{array}$} & \multirow{3}{*}{$\begin{array}{c}\text { B } \\
\text { Coal to wood } \\
\text { conversion factor } \\
\text { (tonnes } \\
\text { of wood per tonne of } \\
\text { coal) }\end{array}$} & \multirow{3}{*}{$\begin{array}{l}\mathrm{C}=\mathrm{A} * \mathrm{~B} \\
\text { Coal to } \\
\text { wood } \\
\text { equivalent } \\
(1,000 \\
\text { metric } \\
\text { tonnes })\end{array}$} & \multicolumn{2}{|c|}{$\mathrm{D}$} & \multicolumn{2}{|c|}{$\mathrm{E}=\mathrm{C} / \mathrm{D}$} & \multicolumn{2}{|c|}{$\mathrm{F}$} \\
\hline & & & & \multicolumn{2}{|c|}{$\begin{array}{l}\text { Wood per } \\
\text { acre } \\
\text { (metric } \\
\text { tonnes) }\end{array}$} & \multicolumn{2}{|c|}{$\begin{array}{c}\text { Total land } \\
\text { equivalents } \\
\text { exported }(1,000 \\
\text { acres) }\end{array}$} & \multicolumn{2}{|c|}{$\begin{array}{l}\text { Total land } \\
\text { equivalents } \\
\text { imported } \\
\text { (1,000 acres) }\end{array}$} \\
\hline & & & & Max. & Min. & Min. & Max. & Min. & Max. \\
\hline 1832 & 2,201 & 3.5 & 7,704 & 1.219 & 0.864 & 6,320 & 8,917 & 14,977 & 16,839 \\
\hline 1849 & 9,742 & 3.5 & 34,097 & 1.219 & 0.864 & 27,971 & 39,464 & 19,800 & 24,177 \\
\hline 1870 & 32,938 & 3.5 & 115,283 & 1.219 & 0.864 & 94,572 & 133,429 & 41,366 & 63,006 \\
\hline 1907 & 88,630 & 3.5 & 310,205 & 1.219 & 0.864 & 254,475 & 359,034 & 126,978 & 186,576 \\
\hline
\end{tabular}

Sources: See Tables 1-5. For the conversion factors, see Theodoridis, 'Ecological footprint'.

The rise of coal embodied in mining itself as a share of embodied coal exports indicates the great increase in the significance of direct exports of coal. In 1832, 1849, and 1870 the direct exports of coal were equivalent to $27 \%, 30 \%$, and $36 \%$ respectively of the sum of coal embodied in exported goods (Table 1). By 1907, net exports of actual coal were almost three times more than coal used in manufactures, reaching approximately 65 million metric tonnes. That accounted for 186-263 million acres, or approximately $70 \%$ of total land embodied in exports in that year, when the possible range of the sum of coal exports and coal embodied in exports was equivalent to approximately 94-133 million acres in 1870 and 254-359 million acres in 1907.

\section{Discussion and conclusion}

In this article we have clearly demonstrated that the role of Britain throughout the nineteenth century was not that which is commonly portrayed in world system studies: of a core appropriating one-way flows of land and resources from abroad. In fact, one should also account for the simultaneous exports and the resources embodied in them in order to be consistent. The relationship that emerges is more multifaceted. This does not negate the importance of imported goods and 'ghost acres', not least as it has been found that, during the earlier years of the nineteenth century, Britain was actually a net appropriator of significant quantities of natural resources and land from abroad. Our understanding of these flows as part of a system alters, however. By at least 1849, Britain had turned into a net exporter of land embodied in commodities, rightly supporting the claim to be the "workshop of the world'.

But even before 1849 and in particular in 1832, the quantitative contribution of imports such as cotton, sugar, and timber was not larger than Britain's own 'vertical frontier' - in other words, coal. In fact, in 1830 total coal output was much higher, in land terms, than the contribution made by cotton, sugar, and wood imports (estimated at 25-30 million acres). 
Total coal output in $c .1832$ made up approximately 31.4 million metric tonnes or, in other words, around 90-127 million acres. ${ }^{35}$ Indeed, for the rest of the nineteenth century, the share of total coal exports and coal embodied in export manufactures had increased to approximately $20-30 \%$ of total coal output, and its land equivalent was enough to counterbalance the land embodied in imports.

Equally, our results present a new picture of the significance of particular products. The textile industry comes to the fore, but in rather different ways from that presented by Pomeranz. Ironically, his method of converting cotton into a counterfactual of land requirements for wool neglected the actual flows of wool, first as an export from Britain, and in the later nineteenth century as inflows from the antipodean colonies. There is no doubt that cotton played a crucial role in the mechanization of textile production, at a time when the demands for cotton-producing land from British manufacturers was comparatively small. ${ }^{36}$ Yet the ecological footprint of woollens was much larger, especially after that industry had adopted similar forms of mechanized production. ${ }^{37}$ This reflects the much greater demand for land entailed in developing production based on animal rather than plant products. High-yielding cotton was an efficient form of utilizing colonial land, but made much greater demands upon labour. Wool was also relatively more significant in terms of the demand for land when seen from the perspective of the British consumer, because a much higher proportion of cottons were exported, and far more woollens were imported from elsewhere. Seen from this consumption perspective (which is not the same as that of tracing the sources of added value in the economy), the demand for cotton was distributed more widely among Britain's trading partners.

The second way in which textiles come to the fore is in the land demands of potash, a source of alkali for many industrial purposes but primarily used for making soft soap and bleaching agents for the woollen and linen industries. ${ }^{38}$ This was the single most important product in British accounts until 1850, after which the artificial production of soda compounds and mineral potash mining supplanted it, although imports remained substantial until the 1870 s. $^{39}$ The actual acreage of timber cleared for potash-making in any given year would be very much smaller than our assigned value, because it would be the accumulation of many years' growth, especially on the land frontier (exactly the same point applies to all measures of the land required for sustainable firewood production). We thus produce a notional figure relating to

35 Coal output is based on Mitchell, British historical statistics, 247. The conversion here is done based on our conversion factors for coal. Nevertheless, even using Pomeranz's more conservative conversion factors, the land equivalent of coal output would be approximately 44 million acres and thus still higher than his estimate of 'ghost acre' imports.

36 Allen, British Industrial Revolution, pp. 182-216; Prasannan Parthasarathi, Why Europe grew rich and Asia did not: global economic divergence, 1600-1850, Cambridge: Cambridge University Press, 2011, pp. 89-114.

37 William Beinart and Lotte Hughes, Environment and empire, Oxford: Oxford University Press, 2007, pp. 93-110.

38 William I. Roberts, 'American potash manufacture before the American revolution', Proceedings of the American Philosophical Society, 116, 5, 1972, pp. 383-95; L. Gittins, 'Innovations in textile bleaching in Britain in the eighteenth century', Business History Review, 53, 2, 1979, pp. 194-204; Miller, 'Potash from wood ashes'.

39 Ludwig Fritz Haber, The chemical industry during the nineteenth century: a study of the economic aspect of applied chemistry in Europe and North America, Oxford: Clarendon Press, 1958; Kenneth Warren, Chemical foundations: the alkali industry in Britain to 1926, Oxford: Clarendon Press, 1980; Miller, 'Potash from wood ashes'; Martin Blake Hocking, Modern chemical technology and emission control, Berlin: Springer, 1985; Colin A. Russell, Chemistry, society and environment: a new history of the British chemical industry, Cambridge: Royal Society of Chemistry, 2000. 
the requirements to sustain the economy over time in the form taken in the benchmark year. To sustain such practices, Britain or its trading partners would have had either to set aside the requisite amount of forest land to allow regrowth, or to continually expand the harvesting frontier. In practice, British consumers were benefiting from the accumulated stock of previous decades' growth, but that practice could only be sustained by continual expansion to exploit new territory. However, it is worth discussing the results after constraining the role of potash. If we halve the land impact of potash, it can be seen that the general results would not be altered significantly. First, potash would continue being the most important imported product in all benchmark years before 1907, while the trade balance for 1832 would still be in deficit. For the rest of the benchmark years, the trade surplus would simply increase and coal would remain most important. Alternatively, when completely excluding potash from our calculations, coal becomes the most significant in the whole period of study, since there is a surplus of land equivalents in trade even for as early in the nineteenth century as 1832 .

Potash being largely a by-product of agricultural activity raises questions of double counting, especially if the cleared land was then used for agricultural exports. In practice this would be extremely rare, and in any case the agricultural production could not take place simultaneously with potash production. More importantly, in the cases of both wool and potash we find regions where the crucial aspect of the labour regime was the expanding settlement frontier of what Alfred Crosby called 'neo-Europes', utilizing both frontier clearance of land and relatively low-intensity work by European settlers to generate resources which were exported back to the metropole. ${ }^{40}$ Somewhat similar regimes may have existed in parts of Russia and Scandinavia, alternative sources of potash. This form of overcoming the land constraint contrasts sharply with the plantation agriculture of the cotton belt and sugar islands, or indeed the cropping regimes of alternative suppliers of cotton in Egypt and South Asia.

In regard to the overall system, we also note the astonishing growth in throughput of landbased products or their equivalents, which grew far more than the value of the economy or trade. The net coal embodied in exports grew by a factor of fifteen between 1832 and 1870 . The net imports of land-based products grew by a factor of more than eleven between 1832 and 1907, but the change would be over a hundred-fold if we disregarded potash. British GDP grew only around five-fold between 1832 and 1907. The total land area of Great Britain is a little less than 59 million acres. By 1832 the 'land' embodied in imports, primarily the potash frontier, was already approaching one-third of this area. By 1870 our estimate of the maximum net import of land-based goods had surpassed the entire area of Great Britain, and by 1907 this was over three times as large, and well over double even with the minimum estimate. Hence, our recalibration of what factors had greater quantitative weight in overcoming the land constraint, and our stress on domestic factors, in no way implies the possibility of selfsufficiency. The presence of an empire, along with its coercive institutions built on colonialism and slavery, was necessary to support this massive flow of resources, and our data underline the profound ecological transformation of the British economy, both in overcoming the land constraint and also in its relationship with both suppliers of raw materials and consumers abroad.

40 Alfred W. Crosby, Ecological imperialism: the biological expansion of Europe, 900-1900, Cambridge: Cambridge University Press, 1986. 
Dimitrios Theodoridis is a researcher at Göteborg University. His research focuses on the interplay between trade and natural resources, with a special focus on colonialism, industrialization, and slavery.

Paul Warde is Reader in Environmental History at the University of Cambridge. His research focuses on environmental and energy history, and the history of economic and environmental thought.

Astrid Kander is a professor in the Department of Economic History at Lund University. Her research focuses on energy and environmental history.

\section{Appendix 1: method}

A detailed discussion for the acreage conversion factor of each product and the coal embodied in it can be found in previous research. ${ }^{41}$ The principal methodological steps followed are outlined here.

Starting with the products that mainly embody land, we must:

1. Identify the products that made any kind of sizeable demand on land. A list of these is provided in Table A2.

2. Identify the physical quantities of traded goods.

3. Use an estimate of land yield for each of these commodities - for instance, metric tonnes per acre.

4. Divide the traded quantity by the acreage yield factor in order to calculate the corresponding amount of land.

Some goods that have little direct impact on the land may have required the use of fuel in their extraction and processing: for instance, metals such as iron, copper, lead, zinc, and tin, or mined minerals. In these cases, only fuel inputs are considered. Working out the coal embodied in products requires a similar set of steps to those outlined above but it is worth outlining them for the sake of clarity.

1. Identify all those traded goods which embodied significant amounts of coal in their total export or import.

2. Isolate the main steps in their production, and the amount of inputs relative to final output. For finished iron goods, for example, these might include the smelting of pig iron, further refining into finished iron or steel intermediary goods, final manufacturing processes, and possibly incorporation as components into final goods for export. Similarly, a good such as beer must take into account sugar and barley used as a basic input, and the fuel used in the malting and brewing process. As well as there being different kinds of input, there will be wastage in the process, such that the input of raw cotton or pig iron will be greater than the weight of the final output. This also raises the

41 For detailed discussion of how the acreage and coal conversion factor of each product has been calculated, see Theodoridis, 'Ecological footprint'; Warde, 'Energy embodied'. 
issue of how we account for fuels that go into processes where there are by-products, making it difficult to clearly allocate a proportion of the fuel (e.g. the coking process). These cases are too complex to elaborate here, but would not alter results significantly.

3. Calculate the coal inputs into each stage of the process (which must include the input of coal into secondary fuels that may be used directly, such as coke or electricity).

4. Calculate the coal that is used as an input into the production of all the coal itself, as this accounted for around $6-7 \%$ of production.

5. Turn the final sum of embodied coal into volumes of firewood and then a land equivalent.

A word must be added on the particularities of wood and wood products. Previous calculations have assessed the land equivalent of coal in terms of the sustainable harvest - that is, the counterfactual amount of land that produces the same amount of thermal energy in a year. ${ }^{42}$ In the circumstances of frontier expansion, we might see the rapid felling of a stock of wood that has accumulated over decades or even centuries. This would mean that the actual area of land exploited would have been very much smaller than that calculated for a sustainable yield. ${ }^{43}$ Because the large-scale international transport of firewood seems never to have been economically viable, this is less a concern for calculating coal equivalents than it is for converting timber imports, and especially wood ash, which presented extraordinarily high demands on wood, into land equivalents. We have chosen to make these calculations as the area of land that would have been required to generate a sustainable yield of the product; in considering the escape from a land constraint, only either a sustainable forestry regime or a continuous expansion of the land frontier on an equivalent scale could have made such a strategy viable. We have discussed this issue in the main article.

42 A sample of these studies includes Wrigley, Continuity, chance and change; Wackernagel and Rees, Our ecological footprint; Pomeranz, Great divergence; Rikard Warlenius, 'Core and periphery in the early modern world system', in Arne Jarrik, Janken Myrdal, and Maria Wallenberg Bondesson, eds., Methods in world history: a critical approach, Lund: Nordic Academic Press, 2016, pp. 185-205.

43 In fact, we have no way of knowing exactly how large this land area was, given that there were no detailed surveys of the state of the forest stock. 


\section{Appendix 2: converted products}

Table A2. List of products included in this study

1832 Products included in Tables 1 and 2: ashes, pearl and pot; butter; cotton, raw cotton, cotton yarn, cotton goods; coal; copper; pig iron; iron and steel; lead; tin; wheat; wool, raw wool, wool yarn, woollen goods; wood Included under 'other': cheese; coffee; corn, barley, oats, rye, peas, beans, maize/indian corn, buckwheat, wheatmeal/flour; dyes, indigo madder, madder root; seeds, flax or lin; silk, raw; skins, goat and lamb; sugar, unrefined; tallow; turpentine; bark for tanners; coconuts; eggs; currants; raisins; hemp, undressed; mahogany; oils, palm, cocoa, olive; rice, unhusked, in-husk; seeds, rape; silk, thrown of all sorts; spices, cassia lignea and cinnamon, cloves, nutmeg, pepper, pimento; tobacco, unmanufactured; wine

Excluded due to double counting: flax/hemp, tow or codilla of hemp and flax - counted land embodied in flax seed; molasses - counted land embodied in sugar; silk, waste knubs and husks - counted land embodied in raw silk; spices, mace - counted land embodied in nutmeg, hides -counted land embodied in tallow

1849 Products included in Tables 1 and 3: ashes, pearl and pot; butter; cotton, raw cotton, cotton yarn, cotton goods; coal; copper; pig iron; iron and steel; lead; zinc; tin; sugar, refined; wheat; wool, raw wool, wool yarn, woollen goods; wood

Included under 'other': cheese; coffee; corn, barley, oats, beans/peas, maize/corn, wheat-meal/flour, other meals; dyes, indigo, cochineal, madder, madder root; lard; oil, olive, palm, coconuts; seeds, flax or lin; silk, raw silk, thrown silk, silk manufactures; sugar, unrefined, refined; tallow; turpentine; animals living, oxen and bulls, cows, calves, sheep and lambs, swine and hogs; bark for tanners; caoutchouc; eggs; currants; raisins; hemp, undressed; mahogany; potatoes; rice, unhusked, in-husk; seeds, rape; spices, cassia lignea and cinnamon, cloves, nutmeg, pepper, pimento; tea; tobacco unmanufactured; wine

Excluded due to double counting: bacon - counted land embodied in lard; beef - counted land embodied in tallow; flax and tow or codilla of hemp and flax - counted land embodied in flax seed; hams - counted land embodied in lard; hides - counted land embodied in tallow; molasses - counted land embodied in sugar; oil seed cakes - counted land embodied in oils; pork salted - counted land embodied in lard; silk, waste knubs and husks - counted land embodied in raw silk; spices, mace - counted land embodied in nutmeg

1870 Products included in Tables 1 and 4: ashes, pearl and pot; butter; cotton, raw cotton, cotton yarn, cotton goods; coal; copper; pig iron; iron and steel; lead; zinc; tin; sugar, refined; wheat; wool, raw wool, wool yarn, woollen goods; wood

Included under 'other': cheese; coffee; corn, barley, oats, beans/peas, maize/corn, wheat-meal/flour, other meal; dyes, indigo cochineal, madder root; hides; bacon; seeds, flax or lin; tallow; animals living, oxen, bulls, cows/ calves, sheep/lambs, swine and hogs; bark for tanners; bark, Peruvian; caoutchouc; gutta percha; hemp, dressed and undressed; jute; hops; oil, palm, coconut, olive; paper; potatoes; eggs; rice, unhusked; seeds, rape; silk, raw silk, thrown silk and yarn, silk manufactures; spices, cinnamon, ginger, nutmeg, pepper, pimento; mahogany; turpentine, common; cocoa; currants; raisins; sugar, refined, unrefined; tea; tobacco; wine

Excluded due to double counting: beef - counted land embodied in tallow; bristles - counted land embodied in bacon; cotton seeds - counted land embodied in cotton; flax dressed and undressed - counted land embodied in flax seed; hides, tanned - counted land embodied in tallow; hides, untanned wet - counted land embodied in tallow; lard - counted land embodied in bacon; molasses - counted land embodied in sugar; oil of turpentine; oil seed cakes - counted land embodied in oils; pork - counted land embodied in bacon; rosin - counting land embodied in turpentine; silk, waste knubs and husks - counted land embodied in raw silk

1907 Products included in Tables 1 and 5: ashes, pearl and pot; butter; cotton, raw cotton, cotton yarn, cotton goods; coal; copper; pig iron; iron and steel; lead; zinc; tin; sugar, refined; machines, steam and non-steam engines; wheat; wool, raw wool, wool yarn, woollen goods; wood

Included under 'other': cheese; corn, barley, oats, beans/peas, maize/corn, wheat-meal/flour, other flour; bacon; mutton; seeds, flax or lin; tallow; turpentine oil; paper pulp of wood, mechanical, chemical; rice; animals living, cattle, sheep and lambs; eggs; hops; oils, coconut, olive, palm; spices, cinnamon, ginger, pepper; onions; potatoes; tomatoes; cocoa, raw; coffee; currants; raisins; hemp, dressed and undressed tow or codilla; jute, raw jute, jute yarn, jute manufactures; silk, raw silk thrown silk and yarn, silk manufactures; caoutchouc; bark, Peruvian; bark for tanning; dyes, indigo; paper; sugar, refined, unrefined; wine; tobacco, unmanufactured; mahogany

Excluded due to double counting: beef - counted land embodied in tallow; cotton seeds - counted land embodied in cotton; flax dressed and undressed - counted land embodied in flax seed; ham - counted land embodied in bacon; hides - counted land embodied in tallow; lard -counted land embodied in bacon; pork - counted land embodied in bacon; rosin - counted land embodied in turpentine; molasses - counted land embodied in sugar 